\title{
Management Practices and Performance of Public hospitals in Uganda
}

\author{
John Bosco Kakooza, Immaculate Tusiime, Hojops Odoch ,Vincent Bagire \\ Department of Business Administration, Makerere University Business School \\ Email: vbagire@mubs.ac.ug
}

\begin{abstract}
The Daily Monitor publications ran serialized articles showing the awful state of government hospitals across the country. While the Ministry of Health insists that the problem is not as bad as it is depicted, the level of service delivery in public hospitals has come under serious public scrutiny espousing the cause for concern about policy, practice and research. There should be glaring gaps in management practices as a possible explanation. In this study, we investigated impact of management decision making, structure, processes, communication and management style on hospital performance. The study has emphasized good management as the determinant of better performance of hospitals in the Ugandan context. Findings of this study challenges policy makers to strengthen management processes in addition to mobilizing financial, human and capital resources for hospitals. The study extends the debate on application of management theory with practice in the health sector in the Ugandan context.
\end{abstract}

Keywords: Marketing practices, ministry of health, management practices hospital resources, ugandan public hospitals

\section{Introduction}

Good management practices are expected to translate into improved service delivery, efficiency and effectiveness in any organizational context. Management practices are interconnected in such ways that they enable efficient functioning of organizations. Management is a wide field with specific disciplines of organizational endeavor and practices varying across firms and industries. Management practices cut across organizational functionality in any discipline. There is inadequate research that has focused specifically on management practices that can sustain efficiency and effectiveness in African organizations (Bagire and Namada, 2015). Ghosal (2005) has posited that several scholars have lately voiced their concerns about the current state of management research and pedagogy. Accordingly, Donaldson (2002) as well as Pfeffer and Fong (2002) stated that there is a lack of impact of management research on management practice. Ghosal (2005) is more explicit in saying that "theory has had negative effect on practice of management; management theories are more causal or functional". The academic fraternity has to critically appraise existing management theories and practices to discover those factors and practices that could strengthen and sustain organizational performance in various African contexts. This study was motivated to examine management practices in the medical sector giving national wide concerns on quality service delivery in public institutions.

The performance of public hospitals in Uganda and indeed the entire health sector is a cause for worry from the perspective of the management knowledge. Bloom et al (2009) have stated that management in hospitals is very poor compared to that of other institutions; it is even worse in public than private hospitals. In the few months of the 2012/13 fiscal year, the performance of the health sector in general and hospitals in particular emerged as an issue of national concern. The outcry has been on lack of funds; the mass media relayed realities of appalling facilities, rundown equipment and apathy among health workers. From the view of management scholars, the system in these public health institutions must be flawing. The government was put on spotlight as a reason for the declining service delivery with rundown facilities, dilapidated premises, unused equipment, congested wards, slow service processes, lack of adequate staffing coupled with low motivation among the available staff and lack of supervision (Okara, 2012). The Daily Monitor publications ran serialized articles showing the state of government ambulances across the country, most of them rotting in parking yards due to lack of repair, fuel or outright neglect (Daily Monitor, September, $9^{\text {th }}, 26^{\text {th }}$, $29^{\text {th }}$ 2012). The blame game regarding the state of public hospitals continues. While the Ministry of Health insists that the problem is not as bad as it is depicted, the level of service delivery in public hospitals has come under serious public scrutiny espousing the cause for concern about policy, practice and research. There should be glaring gaps in management practices as a possible explanation.

\section{Literature review}

The study was guided by the various organizational management theories among which the Systems Theory and the Top Echelons Theory. The Systems Theory presupposes that organizations are built from many parts that must be coordinated to achieve functionality (Laszlo and Krippner, 1997). According to Hambrick and Manson's (1984) Top 
Echelons Theory, organizations are a reflection of their top managers. When an organization is shrouded into poor performance, this means that the top managers have managerial gaps.

\subsection{Management practices}

A management system is the framework of practices through which an organization can fulfill all tasks required to achieve its objectives. The management practices comprise into processes and procedures. A more complete system would include policy structure, decisions points, framework of resource allocation, accountability, communication, schedule for activities to be completed as well as auditing tools to implement corrective actions and creating an upward spiral of continuous improvement. Usha et.al., (2010) have posited that quality management may include what they call soft practices like supervision, inspiration, spirituality leadership and counseling while hard practices include those with physical evidence like communication, structuring and managing facilities. In this study, we considered management decision making, structure, processes, communication and management style.

\subsubsection{Decision-making}

According to Provan (1985), decision system should be enhanced in the structure. For instance, the power a board yields will affect the CEO's decision ability to play a key role in implementing policy. This should also minimize technical complexity to enable operations run smoothly. The regulatory pressure also affects decision-making. When the organization is highly regulated and controlled, perception of uncertainty always looms, hence no policy implementation becomes effective. Strategic decisions are non-programmable decisions that involve the commitment of substantial resources at the level of the total enterprise (Ghemmawat, 1991, cited in Wally and Baum, 1994). The process of choice or decision-making can be conceptualized as involving three intertwined activities namely, intelligence activity, design activity and choice activity (Wally and Baum, 1994). Intelligence activity is environmental scanning that involves gathering and processing of information. This information gathering provides cues for recognizing potential decision situations and formulating alternatives.

\subsubsection{Process}

When performing design activity, decision makers analyze the formulated alternatives to determine likely outcomes and identify alternative outcomes that will satisfy the needs or goals associated with decisions. When performing choice activity, decision makers make judgments, choosing among the identified alternatives. Individual differences among strategic decision makers affect strategic decision-making activities (Hambrick and Finkelstein, 1987). In addition, historically developed organizational and environmental structures constrain strategic decision-making activities (Hitt and Tyler, 1991). Decisions of major consequence occur in response to real life situations. Often these situations are very complex and require decision-making that occurs over lengthy periods. The theoretical framework based on two systems of reasoning draw a distinction between the reasoning processes employed in making these decisions (e.g. Sloman, 1996). One system is purposeful and rational, the other is automatic and affective (Hamilton, Sherman and Maddox, 1999). These systems can coexist and influence decision-making behavior in organizations. The first system or the experiential system describes a fast, effortless, intuitive reasoning process that is subject to emotional influences and is often utilized to make many decisions in a near simultaneous manner. The second system or the rational system describes a slow, effortful, logic-based process that results in decisions made sequentially rather than simultaneously.

\subsubsection{Structure}

The structural form of the organization is an essential factor in determining performance. Ansoff and Mcdonnel (1991) define structure as the arrangement of tasks, roles, authority and responsibility through which a firm does its work. This does not differ much from view of Thompson and Strickland (2001) who posit that structure is no more than the managerial device for facilitating and implementing organizational activities. Structuring refers to activities of setting up organizations and ensuring smooth internal functioning. The key outcome here is having functional units involved in specified processes and roles. Structure specifies the authority levels and hierarchy, task grouping, coordination and those necessary resources to run the organization. Structuring should lead to rational decision making, clear levels of management and enhanced efficiency.

Ruekert et al (1985) emphasize that many organizations give more attention to planning and strategic programs than recognizing the diversity of organizational structures available for implementing such plans; identifying likely impact of structure on the variety of performance dimensions and examining a set of contingent environment factors, which moderate the effects of structure on performance. Thompson and Strickland (2001) and Ruekert (1985) propose operationalization of structure in terms of centralization (decisions shared in the social system), formalization (extent activities are governed by rules, procedures and contracts), complexity (special arrangement of work flow) and standardization (prescribed procedures and practices). These have a common thread with Miller's (1986) description and that of Galan and Sanchez-Bueno (2009). 


\subsubsection{Communication}

Effective communication has long been credited as a prime factor in the attainment of high levels of organizational effectiveness (Greenbaum, 1974). Organizational communication consists of various message sending and receiving phenomena affecting formal social units in which individuals work toward common goals. Organizational communication is defined as a system in terms of purpose, operational procedures, and structure. Zawacki (1974) argued that the achievement of organizational goals is the main purpose of organizational communication; and for organizations to achieve this, they have to employ appropriate communication networks, communication policies and communication activities. However, Bacharach (1977) shows the view that the effect of organizational size, shape, decentralization, routinization and boundary spanning on the frequency of communication between departments heads and subordinates must be well analyzed. Bacharach (1977) discovered that in fewer complexes, in less formal and more decentralized organizations, communication is greater than in complex, formal, centralized organizations. Thus, findings of Greenbaum (1974) demonstrates that even similar organizations might be different in communication dimensions; it was determined that considerable skepticism presently exists between managers and theorists with regard to what barriers are separating theory and practice actually and how they might be overcome.

\subsubsection{Management style}

Waldman et al. (2011) confided that management is difficult to conceptualize, especially, by top executives whose leadership capacity must be used in order to inspire lower organizational levels. Effective management must be seen in participative leadership, as it is stated "research that focuses on management practices while excluding considerations for a firm's leadership qualities is committing an important error of omission" (Waldman et al., 2011). Judge and Piccolo (2004) state unequivocally from a meta-analysis study that good leadership is a tenet for successful management practice. Managers with a style of involvement, participation and consultation will share vision and inspiration among their juniors and in turn improve employee satisfaction through a family-friendly work place. There should not be a management of the status quo, but ongoing learning and adaptability. This has been reaffirmed by Bloom, Genakos, Martin and Sadun (2011).

Management style among other practices is influenced by cross-cultural differences by acts, perceptions and expectations for management practices. Culture influences good management practice. For instance, Waldman et al. (2011) dismisses an earlier study by Bloom et al. (2011) for narrowing management practices to monitoring, targets and incentives against hard practices like team-based leadership which is universal to effectiveness. Rowold and Schlutz (2009) also emphasized transformational and transactional leadership as basic tenets in any management style.

\subsection{Hospital Management and performance}

Hospital management has been defined to include the responsibility and accountability for the overall operation of the organization (Bohen, 1995). More specifically, hospital management has been conceived as a shared process of toplevel organizational leadership, policymaking and decision-making. Hospital management was regarded by scholars as a unique form away from the conventional management. Although the governing board has the ultimate accountability, the CEO, senior management and clinical leaders are involved in top-level functions (Bader, 1993; Alexander et al. 2003).Most hospitals have their own management board and a professional team of executive managers. They constitute the axis of "hospital management" together, which is the process of steering the overall functioning and effective performance of a hospital; defining the hospital's mission, setting its objectives, supporting and monitoring their realization at the operational level (Flynn, 2002; Eeckloo et al., 2004). Efficient management of hospitals requires responsible and effective use of funds, professional management and competent governing structures (Ditzel et al., 2006).

The size of the hospital board is an important element in its overall management structure. It has been argued that a board's ability to monitor and make important decision improves with its size. This is because there is a need to ensure diversity of perspectives, backgrounds, expertise and experience within the board. However, Hermalin and Weisbach (2003) argued that there is a possibility that larger boards can be less effective than small boards. When boards consist of too many members, agency problems may increase as some directors may tag along as free-riders. Maintaining a small board size is likely to result in the board's ability to give more effective oversight for the management of the hospital. Jensen (1993) argues that there should be an upper limit to board membership to make it an effective governance mechanism. In practice, determining an optimal board size may be dependent on the size of the hospital and its scope of operation. However, Lipton and Lorch (1992) recommended limiting the number of directors to seven or eight, as numbers beyond that would be difficult for the CEO to control.

Performance of hospitals has not had consensus among scholars. Provan (1985) has outlined performance in hospitals in terms of bed occupancy, costs, mortality rate, payroll ratios, accreditation, growth, resource acquisition. He however concedes that these measures lack generalizability. Bloom et al. (2009) state that management in hospitals is poorly alike with that of manufacturing firms. What is more, public hospitals have worse practices than private ones. In the public hospitals, hospital administrators must make decisions that foster the highest standards of patient care and 
achieve financial performance, as measured by more traditional metrics such as return on equity, return on assets, occupancy rates. Hence, strategic decisions made by hospital administrators have considerable consequences. Healthcare institutions pose unique problems for management since organizational decision makers must consider elements such as patient access to services, reliability and quality of care. These elements distinguish hospitals from other types of consumer organizations since failures in these areas, even on a small scale, could result in the loss of life (Ray, Plowman and Mcdaniel). Furthermore, hospitals are further distinguished by diverse training, experiences, and responsibilities; inherently present issues about how to work together (Ashmos, Huonker and McDaniel, 1998).

Hospital management requires a close network of decision makers to cater for the diversity of quality decisions required. Kissi (2008) emphasized the need for participation. Within the hospital, segregated groups with varying educational backgrounds should lead to quality decisions. Ray et al (n.d) have argued that boards, directors, administrators and nurses should participate in different decision stages since each group has its own information needs. They demonstrate a simple model where better decision making leads to quality decision outcomes which in turn results in better hospital performance. Taking caution of contradictory results by Goldstein and Ward (2004) and Kaisi (2008), Ray et al (n.d) advocate for increasing participation in the activities of generating, evaluating and choosing alternatives, which should result in hospital benefits. From the review we draw the main hypothesis that,

H1Management practices will have a significant relationship with hospital performance.

HIa: Decision-making will have a significant positive relationship with performance;

H1b: Structures will have a significant positive relationship with performance;

HIc: Management process will have a significant positive relationship with performance;

H1d: Management style will have a significant positive relationship with performance;

Hle: Communication will have a significant positive relationship with performance.

\section{Methodology}

We used a cross sectional survey design. Cross sectional studies view the existence of phenomena at a given point in time when data is collected. The population identified for this study was public hospitals in Uganda. The choice was based on the public and outstanding outcry that facilities and performance in public health institutions were more appalling compared to the private ones. The sampling frame for this study was all the listed 52 public hospitals in the country. The unit of analysis was the hospital. We chose to have four respondents per hospital to eliminate common internal biases that could lead to skewed data. The respondents were the medical superintendent, as the chief administrative and medical head of the hospital; others were the hospital administrator and two senior medical officers. Primary data was collected from the respondents using a structured questionnaire on a five point Likert scale. We considered both tangible and intangible measures of performance. The total respondents expected and thus questionnaires rolled out were 208. We had 137 questionnaires back from 40 hospitals.

\section{Results and discussion}

We first determined the Pearson moment correlation coefficients among the management constructs and performance. The results are in the table 1 .

Table 4-1 Pearson Correlation results of management constructs and performance in hospitals

\begin{tabular}{|c|c|c|c|c|c|c|c|c|}
\hline & & 1 & 2 & 3 & 4 & 5 & 6 & 7 \\
\hline 1. & Decision making & 1 & & & & & & \\
\hline 2. & Management process & $.778^{* * *}$ & 1 & & & & & \\
\hline 3. & Management Structure & $.644^{* * *}$ & $.780^{* *}$ & 1 & & & & \\
\hline 4. & Management style & $.609^{* *}$ & $.777^{* *}$ & $.743^{* *}$ & 1 & & & \\
\hline 5. & Communication & $.618^{* * *}$ & $.789^{* *}$ & $.732^{* *}$ & $.751^{* *}$ & 1 & & \\
\hline 6. & Management Practices & & & & & & 1 & $.838 * *$ \\
\hline 7. & Performance & $.692^{* *}$ & $.726^{* *}$ & $.724^{* *}$ & $.742^{* *}$ & $.810^{* *}$ & & 1 \\
\hline
\end{tabular}

** Correlation is significant at the 0.01 level (2-tailed).

* Correlation is significant at the 0.05 level (2-tailed).

The correlation analysis with all the domains showed positive and significant coefficients. Among the sub-variables and performance, the highest association was between management communication and performance, followed by management style and performance. The lowest association was identified between decision-making and performance. Our focus here is drawn to management practice and performance as the main variables on which further analysis will anchor. The association between the aggregate management practices has a stronger effect on performance than any other associations. We shall discern the issues behind this pattern in the discussion after examining the regression results. 
We used linear regression analysis to determine the independent effect of each of the management sub variables. The regression results are presented in table 2 .

\section{Table 4-2 Regression results for independent effect of management variables to performance}

\begin{tabular}{llllllc} 
Model & $\mathbf{R}^{\mathbf{2}}$ & $\mathbf{R}^{\mathbf{2}} \mathbf{A d j}$ & $\mathbf{\Delta} \mathbf{R}^{\mathbf{2}}$ & $\mathbf{F}$ change & Sig & S/error \\
\hline $\begin{array}{l}\text { Control variables } \\
\text { (Years of hospital }\end{array}$ & .035 &.-051 & .035 & .407 & .749 & 1.018 \\
$\begin{array}{l}\text { Bed capacity } \\
\text { Board size) }\end{array}$ & & & & & \\
Predictors & & & & & & \\
Decision making & & & & & & \\
Processes & .516 & .458 & .482 & 32.879 & .000 & .731 \\
Structure & .560 & .507 & .526 & 39.440 & .000 & .697 \\
Management style & .612 & .565 & .577 & 49.100 & .000 & .655 \\
Communication & .597 & .548 & .562 & 48.027 & .000 & .668 \\
Management practices & .682 & .644 & .648 & 67.314 & .000 & .593 \\
&. $\mathbf{8 7 4}$ &. $\mathbf{7 6 4}$ & $\mathbf{. 7 3 6}$ & $\mathbf{2 6 . 7 2 4}$ & $\mathbf{. 0 0 0}$ & $\mathbf{. 5 1 1}$
\end{tabular}

In table above, we tested for the independent effect of each of the sub-variables of management before testing the composite variable. As noted from various scholars, the various components of management come into play as functional areas contributing to the aggregate management. In the same vain, each aspect of management may influence performance in specific ways. Thus, for each sub-variable, we controlled for age in years of the hospital, bed capacity and board size in the first model then entered and tested its independent effect. The control variables were not statistically significant in this analysis. The results showed that all the sub variables were statistically significant. Their account to the variation in performance however differed.

Communication emerged with the highest independent effect on performance accounting for $64.4 \%$; structure followed predicting nearly $56.5 \%$ variation in hospital management. The lowest effect was from decision making at $\mathrm{R} 2=.458$. The rest of the variables had moderate effects. Management practices as a composite variable accounted for $76.4 \%$ variation in hospital performance and statistically significant at $\mathrm{p}=.000$. The standard error of the estimate was .511 .

We thus fail to reject $\mathrm{H} 1$ and all sub-hypotheses. We conclude that management practices significantly influence hospital performance. The result also confirm that decision-making, management processes, structure, style and communication significantly influence hospital performance.

\section{Discussion of the findings}

The anecdotal evidences of management practices that influence the performance of public hospitals in Uganda indicated that each component had varying contribution towards explaining this pedagogy. This study revealed that the public concerns have not factored management practices as possible factors to explain the hospital phenomena. The local press and public voices have pointed at lack of funding, equipment, lack of drugs, weak supervision, political interference and lack of adequate staffing. We however, provide an empirical framework showing how management practices are significant. The result showing that communication had the highest effect independently agrees with Greenbaum (1974) who called it a prime factor. Communication has long been counted as key factor in organizational effectiveness. It links the sub-systems of the organization to enable different actors do their work that knits into coherence. Communication leads to achievement of goals (Zawacki, 1974) and therefore the large coefficient in this study is not farfetched. Hospitals are complex systems where quick and efficient communication is necessary for work processes to go on uninterrupted.

The finding that decision-making had the lowest prediction power to performance in our study may not be generalized. It is explained by taking Provan's (1985) conclusion that decision system is supported by the structure. We noted that the decision hierarchy in hospitals was not well defined. The boards, which would be expected as key decision makers in management, were weak; key decisions were said to come either from the ministry or from the district authorities. Hitt and Tyler (1991) who emphasized that structures constrain decision-making also support this. From our discernment, it was also possible that given the nature of specializations by medical personnel, many operational decisions emerged from their work centers and tasks. The conclusions by Kaissi (2008) and Ray et al (n.d) on participation in decision-making are vital to this finding. The lack of participation and involvement of the various technical groups like nurses, doctors, pharmacists, engineers etc. in general management decision making would never lead to quality decisions in the hospital.

In view of Hambrick and Mason's upper echelons theory, hospital superintendents as CEOs bear the image of the hospital. However, the lack of consensus on performance measurements in hospitals limits how much they can count in their managerial prerogative. As noted by Hamilton, Sherman and Maddox (1999) some processes are purposeful, others rational or even automatic. I complex hospitals these coexist and influence managerial behavior. These findings 
also have common threads with aspects of Thompson and Strickland's (2001) operationalization of structure in terms of centralization, formalization, complexity and standardization. All these seemed to apply in the hospital system as seen in the close coefficients of the sub variables except communication. The debate between Waldman et al. (2011) and Bloom et al. (2011) may support these results. We agree with the opinion of Ditzel et al. (2006) that efficient management of hospitals requires configuration of effective use of funds, professional management and competent governing structures.

\section{Conclusions and implications}

The study has emphasized good management as the determinant of better performance of hospitals in the Ugandan context. We recognize that performance of public hospitals had been narrowly interpreted and thus seen as negative on the larger scale. Many underlying measures have been neglected. We assessed both tangible and intangible indicators. The results attested that hospitals are performing poorly on some measures and above average on others. The outstanding concerns were on service delivery, which was grossly poor in the eyes of the public.

Our direction of study was to test for the influence of management practices away from the anecdotal evidences of lack of funds, poor staffing and other general factors. There were imminent gaps in planning, decision-making, teamwork, accountability, human resource management, communication, management structures and style. Thus, we infer that the weak management practices are restraining the efficiency and effectiveness of quality services delivery. This study has empirically reaffirmed the public outcry on the performance of public hospitals in Uganda but provided to policy makers, practitioners and future researchers a new lens to understand the problem. Managers in the hospitals will recognize the gaps that are pertinent in their work. We opine that even where resources are inadequate it is upon hospital managers to communicate to key stakeholders especially the public and within limits provide a service that will be appreciated. Policy makers are challenged to strengthen management processes in addition to mobilizing financial, human and capital resources for hospitals. The study extends the debate on application of management theory with practice in the health sector in the Ugandan context. These results could be generalized to the African reality.

The study of this magnitude was faced with methodological limitations; the operationalization of the study variables could have had some interpretation shortfalls. Much of the extant literature that we accessed was in non-African contexts and in business organizations. Therefore, our results should be interpreted in light of the setting that we studied. Our conceptual framework was anchored in management theory albeit not strongly as relevant literature was scanty. We however, contend that the findings of this study bear credence and will provide key insights for managers, policy makers and scholars.

\section{References}

- Akingbola Kunle (2006). Strategy choices and change in Non-profit organizations. Strategic Change. 15. 265 -281 .

- Analoui, F. and Samour, A. (2012). The Managers characteristics and their strategy development in the Palestinian NGOs. Journal of Management Development, Vol. 31, No. 7, 691 - 699.

- Andres, P. D., Azofra, V. Lopez, F. (2005). Corporate Boards in OECD Countries: Size, Composition, Functioning and Effectiveness. Corporate Governance, 13(2), 197-210.

- Ansoff, H. I. and McDonnell, E. J. (1990). Implanting strategic management. $2^{\text {nd }}$ ed. San Diego, Prentice Hall.

- Ashmos, D. P., Huonker, J. W., and McDaniel, R. R. 1998. Participation as a complicating mechanism: The effect of clinical professional and middle manager participation on hospital performance. Health Care Management Review, 23(4), 7-20.

- Bacharach, S.B (1977). Communication in Administrative Bureaucracies Academy of Management Journal, Vol. 20. No. 3, 365-377.

- Bader, B.S. (1993). “CQI progress report”, Healthcare Executive, September-October, pp. 8-11.

- Bagire, V. and J. Namada (2013). Managerial competencies, financial capability and the level of strategic planning in Ugandan organizations. American Journal of International Business and Management. Vol. 3. 480 - 487 DOI. org/10.4236/ajibm.2013.35055

- Bagire, V., Aosa, E., and Z., B., Awino (2012a). The Strategy - Resource configurations and performance implications in Nongovernmental organizations. Crown Research in Education, Vol. 2, Issue 3. $105-112$

- Bagire, V. and J. Namada (2015) Management Theory, Research and Practice for Sustainable Development in Africa: A Commentary from a Practitioner's Perspective Africa Journal of Management.

- $\quad$ Bartlett, J. E., Kotrlik, J.W, and Higgins, C. (2001). Organizational Research:

- Determining appropriate sample size in survey research. Information Technology, Learning, and Performance Journal. 19 (1). 43-50.

- Bloom, N., Genakos, C., Sadun, R., and Van Reenen, J. (2011). Management practices across firms and countries. Academy of Management practices, 25 (1) $12-33$ 
- Bloom, N., and V., J., Reenen ( 2010). Why do management practices differ across firms andcountries? Occasional paper No. 26. Center for Economic performance, London School of Economics and Political Science

- Bloom, N., Propper, C., Seiler, J., Reenen, J.,V. (2009). Management practices in Hospitals. Health Econometrics and Data Group, Paper 09/23, University of York, July 2009.

- $\quad$ Bohen, L.S. (1995). Your Role as a Trustee, Ontario Hospital Association, Toronto.

- Donaldson, L. (2002). Dammed by our own theories: contradictions between theories and management education. Academy of Management Learning and Education 1. 1.96-106

- Dutta, S., Narasimhan,O.M, and Rajiv,S.(2005). Conceptualizing and measuring capabilities: Methodology and empirical application. Strategic Management Journal. 26. 277 - 285.

- Eeckloo, K., Van Herck, G., Van Hulle, C. and Vleugels, A. (2004). From corporate governance to hospital governance: authority, transparency and accountability of Belgian non-profit hospitals' board and management. Health Policy, Vol. 68, 1-15.

- $\quad$ Ethiraj, S., Kale, K, P.M., Krishinan,S. and Singh, J.V. (2005). Where do capabilities come from and how do they matter. A study in the software services industry. Strategic Management Journal. 26. 25 - 45.

- $\quad$ Flynn, R. (2002). Clinical governance and governmentality. Health, Risk and Society, Vol. 4 No. 2, 155-73.

- Galan, I.J. and Sanchez Bueno. M.S. (2009). Continuing validity of strategy-structure nexus, new findings. Strategic Management Journal. 30. 1234-1243.

- Ghoshal,S. (2005). Bad Management Theories and Destroying Good Management Practices. Academy of Management Learning and Education, 4. 1. 75 - 91

- Goldstein, S. and Ward, P. 2004. Performance Effects of Physicians' Involvement in Hospital Strategic Decisions. Journal of Service Research, 6(4): 361-372.

- Greenbaum, H.H. (1974). The Audit of Organizational Communication. Academy of Management Journal. Vol. 17, No. 4739 - 754

- Hamilton, Sherman, and Maddox (1999) as cited in Leaptrott, J. and J.M. Mcdonald (2008). Assessing managerial decisions using the dual system theory of reasoning: future challenges for management researchers. Academy of Entrepreneurship Journal, Volume 14, Number 2, 2008

- Hambrick, D. C., and Finkelstein, S. (1987). Managerial discretion: A bridge between polar views of organizational outcomes. Research in Organizational Behavior, 9: 369- 406.

- Hambrick, D. C. and Mason, P. A. (1984). Upper echelons: The organization as a reflection of its top managers. Academy of Management Review, 9. (2). 193-206.

- Helfat, C. E. and Peteraf, M. A. (2003). The dynamic Resource based view: Capability life cycles. Strategic Management Journal. 24. 997 - 1010.

- Hitt. M. A., and Tyler, B. B. 1991. Strategic decision models: Integrating different perspectives. Strategic Management Journal, 12, 327-351.

- Judge, T. A., and Piccolo, R., F. (2004). Transformational and Transactional leadership: A meta-analytic test of their relative validity. Journal of Applied Psychology, 89, 755 - 768

- Kaissi, A.A. (2008). Strategic planning processes and Hospital Financial performance. Journal of Health Care Management. 53 (3), $197-2008$

- Kaplan, R. and Norton, D. (1996). Linking the Balanced Score Card to Strategy. California Management Review. 39 (1). 53 - 79.

- Kushner, R.J. and Poole, P.P. (1996). Exploring structure-effectiveness relationships in Non-profit art organizations. Non-profit Management and Leadership.7. $119-136$.

- Laszlo, A., and S., Krippner (1997). Published in The Systems theories and A priori aspect of perception by J.S. Jordan (Ed). 1998, Elsevier Science, Amsterdam, pp 47 - 74.

- Linda, A. H (20030. Becoming a Manager; How New managers master the challenges of leadership. Harvard Business Review Press, Boston, USA

- Lipton, M, J.W, Lorsch (1992). A modest proposal for improved corporate governance, Business Lawyer, 48(1), 59- 77

- Marlin, D., Ritchie, W. J. and Geiger, S.W. (2009). Strategic group membership and Non-profit organization. Non-profit Management and Leadership.20 (1). 23- 39.

- Miller, D. (1986). Configurations of strategy and structure: Towards a synthesis. Strategic Management Journal. 7. $233-249$.

- Mugenda, O. M. and Mugenda, A.G. (2003). Research methods: Qualitative and Quantitative approaches. African Centre for Technology Studies, Nairobi, Kenya.

- Newbert, Scott, L. (2007). Empirical research on the Resource based view of the firm: An assessment and suggestions for future research. Strategic Management Journal. 28. 121 - 146.

- Nunnaly,P (1978). Psychometric Theory, New York, Mcgraw Hill.

- Okara, J., W. (2012). Yes, the health system is awful and we need concerted efforts to improve it. Daily Monitor of 9th, September, 2012, pp 22 
- O'Regan, N., Sims, M.A. and Gallear. D. (2008). Leaders, loungers, laggard: The strategic planning environment-performance relationship re-visited in manufacturing SMEs, Journal of Manufacturing Technology Management. 19 (1). 6-21.

- Peteraf, M.A. (1993). The cornerstones of competitive advantage: A resource based view. Strategic Management Journal. 14 (3). 179 - 191.

- Pfeffer, J. and Fong,C.T (2002). The end of Business Schools? Less success than meets t he eye. Academy of Management Learning and Education. 1.(1). 78- 95

- Provan, K. (1985) Implementation of Effective Management policies in Non for profit Hospitals. Academy of Management proceedings, $309-323$

- $\quad$ Ray, J.L, Plowman, D.A. and McDaniel, R.R (n.d). Participation in decision making one more time: A look at hospital decision making and performance. Academy of Management Annual Meeting Proceedings.

- $\quad$ Rowold, J. and Schlutz, W. (2009). Transformational and Transactional leadership and Followers' chronic stress. Leadership Review, vol. 9. 35 - 48

- $\quad$ Ruekert,R.W., Walker,O.C., Roenng,K.J. (1985). The Organization of marketing activities: A contingency theory of structure and performance. Journal of marketing. Vol.

- Siciliano, J.I. (1997). Relationship between planning and performance in non-profit organizations. Non-profit Management and Leadership. 7 (4). 387 - 403.

- Sloman, S. A. (1996). The empirical case for two systems of reasoning. Psychological Bulletin, 119(1), 3-22.

- Sweet, S. A. and Karen, GM. (2008). Data Analysis with SPSS, 4th edition. Pearson Education

- Thompson, A. A. and Strickland, A. J. (2001). Strategic management: Concepts and cases. 12th ed. Irwin, McGraw Hill

- Tomita, V., Stuparu, D., Stanciu,M., Danisa,C-I (2010). The Effect of organizational culture on quality management practices. Economics, Management and Financial markets. Vol. 5. No. 2, $304-309$

- Topping, S., and Hernandez, S. R. 1991. Health Care Strategy research, 1985-1990: A critical review. Medical Care Review, 48(1), 47-89.

- Usha, L., Damodar, S., and Pratap, K.J.M. (2010). Soft and Hard Aspects of Quality Management Practices Influencing Service Quality and Customer Satisfaction in Manufacturing-oriented Services. Global Business Review 11, 79-101

- Waldman, D.,A., Sally de Lugue,M.,Wang,D. (2011). What can we really learn about management practices across firms and countries?. Academy of Management Perspectives, 3440

- Wally, S. and Baum, J.R. (1994). Personal and Structural determinants of the pace of strategic decisionmaking, Academy of Management Journal. Vol. 37. No. 4932 - 956

- Wernerfelt, B. (1984). A Resource-based view of the firm. Strategic Management Journal. 5 (2). 171-180.

- Wernerfelt, B. (1995). The Resource-based view of the firm: Ten years after. Strategic Management Journal. 16. $171-174$.

- Zawacki, R. (1974). The Performance appraisal and development process: A trend toward increased communication. Academy of Management proceedings. 